\title{
In vitro regeneration and conservation of Indigo (Indigofera tinctoria L.) by slow growth induction
}

\author{
Nair D.S. ${ }^{1 *}$, Reghunath B.R. ${ }^{2}$, Soni K.B. ${ }^{3}$, Alex S . \\ ${ }^{1}$ Department of Plantation Crops \& Spices, College of Agriculture, Vellayani, Thiruvananthapuram-695522, Kerala, India \\ ${ }^{2,3,4}$ Department of Plant Biotechnology, College of Agriculture, Vellayani, Thiruvananthapuram-695522, Kerala, India
}

\begin{abstract}
An efficient protocol for rapid in vitro clonal propagation has been established. Shoot proliferation was obtained from nodal explants in Murashige and Skoog medium supplemented with $1.0 \mathrm{mg} \mathrm{L}^{-1} B A$ and $0.1 \mathrm{mg} \mathrm{L}^{-1}$ IAA. The shoots were subsequently subcultured every four weeks. The shoots were then rooted in vitro in MS medium supplemented with varying concentrations of auxins. The most efficient rooting was observed in MS supplemented with $1.5 \mathrm{mg} \mathrm{L}^{-1}$ IAA. The effective acclimatization (91.67 per cent) was obtained in sterilized sand. Slow growth was induced with varying concentration of mannitol $\left(5 \mathrm{~g} \mathrm{~L}^{-1}\right.$ to $30 \mathrm{~g} \mathrm{~L}^{-1}$ ). Maximum slow growth induction with $100 \mathrm{per}$ cent regeneration was recorded in mannitol $\left(10 \mathrm{~g} \mathrm{~L}^{-1}\right)$ supplemented medium. After 28 weeks in slow growth medium, cultures when transferred to shoot proliferation medium gave 100 per cent regeneration. The regenerants from slow growth induction were found to be genetically stable.
\end{abstract}

Keywords-Axillary meristem culture, genetic stability, in vitro conservation, shoot proliferation, slow growth induction.

Highlights

- In vitro regeneration system via axillary shoot proliferation was established using nodal segments in Indigofera tinctoria

- Slow growth was induced in Indigofera cultures by the addition of the osmoticum, mannitol to the medium,

\section{INTRODUCTION}

Indigofera tinctoria $\mathrm{L}$., popularly known as True Indigo is a shrubby perennial legume valued for its indigo dye and medicinal properties. Indigo dye, is a popular entity of international commerce. It is distributed in India, China, Thailand and other countries of the east and is exploited as a source of natural indigo (Evans 1990; Mattapha and Chantaranothai 2012). The indigenous system of medicine in India uses I. tinctoria in the preparations for treating jaundice, hydrophobia, epilepsy, nervous disorders, bronchitis, sores, ulcers, piles and hemorrhoids
(Saravankumar et al. 2009; Asuntha et al. 2010; Madhanmohan et al. 2010; Muthulingam et al. 2010). Besides, the plant is antibacterial, antioxidant (Renukadevi and Sultana 2011), anti-cancer (Cragg and Newman 2006) and antidiabetic (Bangar and Saralaya 2011). The extract of leaves has remarkable effect on hair growth and in preventing juvenile greying of hair (Joy et al. 1998; Motamarri et al. 2012). Cosmetic, pharmaceutical and dye industry largely depends on Indigofera tinctoria. This plant is at the verge of being endangered due to its overexploitation and collection from the wild (Verma et al. 2012).

Conventional seed propagation of I. tinctoria is beset with many problems that restrict their multiplication on a large scale. Propagation through seed is often unreliable due to poor seed viability and hard seed coat. Its inherent qualities and restricted distribution, provides justification for development of in vitro techniques for mass propagation and conservation of this threatened species. Moreover, conservation of the plants can be accomplished by cultivating and maintaining plants through long term preservation of plant propagules in plant tissue culture repositories. Such ex situ techniques would complement in situ conservation of managing the wild population in their natural habitat. The risk of seed-borne pests and pathogens makes seed a poor candidate for germplasm exchange programs. In vitro grown plantlets/cultures are preferred for germplasm exchange to overcome these problems (Rao 2004). In vitro culture offers options for slow growth technique for short to medium term conservation and cryopreservation for long term conservation. Standardization of an efficient in vitro regeneration system is a prerequisite for germplasm conservation in vitro. Slow growth procedure is based on the manipulation of culture conditions or culture media to allow cultures to remain viable but with a slow growth rate. Cultures could be maintained for longer duration without frequent subculturing. This would substantially reduce the cost of labour and resource materials used in frequent subculturing. 
In vitro culture offers a rapid means of producing disease free clonal planting material and conservation of elite and rare germplasm. Preservation of genetic stability in micropropagation of plants is of utmost importance. Genetically stable and true to type progenies could be obtained through axillary bud culture in vitro (Barik et al. 2007). For any in vitro culture system, maintenance of genetic integrity of regenerated plantlets is of prime concern. To this date, an efficient in vitro regeneration system has not been developed in I. tinctoria.

The objective of our study was to develop an efficient regeneration system by optimizing the culture media for the initiation, proliferation and elongation of shoots from nodal explants of I. tinctoria through enhanced release of axillary buds and adventitious bud regeneration and shoot proliferation from leaf segments, inducing rooting of microshoots and establishing the plants ex vitro. Short term conservation by slow growth induction by addition of mannitol as osmoticum was also analysed in this paper. As any in vitro conservation system is expected to maintain the genetic stability, the in vitro regenerated plantlets were checked for any fidelity using random amplified polymorphic DNA (RAPD) analysis. This protocol would serve for mass multiplication, germplasm conservation and in vitro crop improvement programmes.

\section{MATERIALS AND METHODS}

\section{Preparation of explants}

The seeds for the study were extracted from mature ripe pods harvested from I. tinctoria plants maintained at the Instructional Farm, College of Agriculture, Vellayani, India. They were disinfected with $0.08 \%$ (v/v) mercuric chloride for $15 \mathrm{~min}$. Seedlings were raised in vitro in MS medium (Murashige and Skoog 1962) devoid of any growth regulator but supplemented with $30 \mathrm{~g} \mathrm{~L}^{-1}$ Sucrose. Nodal explants, $0.5-0.8 \mathrm{~cm}$ in length, with single axillary bud and leaf bits of size c.a. $1.0 \mathrm{~cm}^{2}$ excised from 14 day old in vitro raised seedlings were tried for adventitious bud formation and further shoot proliferation. The explants were cultured on MS medium supplemented with different combinations of cytokinins, N6-benzyl adenine (BA) and 6furfurylaminopurine $(\mathrm{Kn})$ at concentrations of 0.1 to $1.0 \mathrm{mg}$ $\mathrm{L}^{-1}$, the auxin indole-3-acetic acid (IAA) at 0.05 to $0.1 \mathrm{mg}$ $\mathrm{L}^{-1}$, and sucrose at $30 \mathrm{~g} \mathrm{~L}^{-1}$. The number of days for bud initiation, number of shoots produced, and numbers of nodes per shoot were recorded and the mean value calculated. Each treatment was replicated six times and experiment repeated thrice.
The regenerated shoots were excised from primary cultures after four weeks of culture and further subcultured on to shoot proliferation medium upto five subcultures. The microshoots of about 1-2 $\mathrm{cm}$ long were then excised and transferred one shoot per test tube, on to the same medium supplemented with varying levels of $\mathrm{GA}_{3}\left(1,2,3 \mathrm{mg} \mathrm{L}^{-1}\right)$ for shoot elongation. The GA level that gave maximum elongation was to be selected as the shoot elongation medium. The treatments were replicated six times.

After another four weeks of culture in the elongation medium, the shoots measuring c.a. $5.0 \mathrm{~cm}$ in length were transferred to half strength MS liquid medium supplemented with varying levels of auxins, indole butric acid (IBA) $\left(0.5\right.$ to $\left.2.5 \mathrm{mg} \mathrm{L}^{-1}\right)$, IAA ( 1 to $2.5 \mathrm{mg} \mathrm{L}^{-1}$ ) and naphthalene acetic acid (NAA) (0.5 to $\left.2 \mathrm{mg} \mathrm{L}^{-1}\right)$ for the induction of rooting. After four weeks, the percentage of shoots forming roots, number of days for root initiation, number of roots per shoot and length of roots were assessed.

The $\mathrm{pH}$ of culture medium at all the stages was adjusted to 5.7 with $0.1 \mathrm{~N} \mathrm{NaOH}$ or $0.1 \mathrm{~N} \mathrm{HCl}$ prior to adding agar $0.8 \% \quad(\mathrm{w} / \mathrm{v})$ (Merck). Culture tubes $(25 \times 150 \mathrm{~mm})$ dispensed with $15 \mathrm{ml}$ of medium were steam sterilized at $121^{\circ} \mathrm{C}$ and $1.05 \mathrm{~kg} \mathrm{~cm}^{-2}$ for $20 \mathrm{~min}$. The cultures were incubated in a culture room maintained at light intensity of $40 \mu \mathrm{E} \mathrm{m}^{-2} \mathrm{~s}^{-1}$ using white fluorescent tube lights for a period of $16 \mathrm{~h}$ light and $8 \mathrm{~h}$ darkness. The temperature of $20 \pm 2^{\circ} \mathrm{C}$ and relative humidity 60 per cent were maintained in the incubation room.

Healthy plantlets with well developed roots were then removed from culture, washed thoroughly with running tap water to remove the adhering gel. The rooted shoots were planted in $10 \mathrm{~cm}$ diameter plastic cups containing different autoclaved potting media (sand, soilrite, soilrite : sand (2:1). The cups were provided with 4-6 drainage holes. The plantlets were then transferred to mist chamber for acclimatization for four weeks. Intermittent misting was given at the rate of two min at $30 \mathrm{~min}$ interval. Liquid MS medium at 10 per cent concentration was sprayed on the plants twice a week. After three weeks, polythene bags were removed and pots were transferred to the field, placed under shade and observations on survival were recorded.

Alternately, ex vitro rooting was also tried with microshoots. Well developed shoots having 3-8 cm length from the elongation medium were separated and were given quick dip (pulsing) and slow dip methods of hormone treatment with IBA. The microshoots were dipped for $20 \mathrm{~s}$ in two concentration levels (1000 $\mathrm{mg} \mathrm{L}^{-1}$ and $500 \mathrm{mg} \mathrm{L}^{-1}$ ) of IBA for pulsing. In slow dip method, the plantlets were kept in IBA $100 \mathrm{mg} \mathrm{L}^{-1}$ solution for $20 \mathrm{~h}$. The treated plantlets were planted out in autoclaved sand as 
potting media. After four weeks of planting out, percentage survival of plantlets were assessed.

\section{Short term conservation by slow growth induction using} mannitol

Nodal cuttings with single axillary bud from in vitro raised cultures were used as the explants for slow growth induction.

\section{Basal slow growth medium}

Full strength and half strength (macro \& micro nutrients) MS medium with and without IBA $0.5 \mathrm{mg} \mathrm{L}^{-1}$ supplemented with $30 \mathrm{~g} \mathrm{~L}^{-1}$ of sucrose and gelled with $0.8 \%$ $\mathrm{v} / \mathrm{v}$ agar were tried for establishing the basal culture media for slow growth. The treatments were replicated six times. The observations were recorded after 16 weeks of incubation. Culture medium which recorded the lowest plant height and late/ no senescence was selected as the basal slow growth medium. Rooting percentage was also recorded in each treatment.

\section{Slow growth induction}

The $5 \mathrm{~mm}$ long nodal segments with one axillary bud dissected from one month old stock cultures (fourth subculture), were used as the starter plant material for slow growth storage. The nodal segments were stored on selected basal slow growth culture medium supplemented with different levels of mannitol ranging from $5 \mathrm{~g} \mathrm{~L}^{-1}$ to 30 $\mathrm{g} \mathrm{L}^{-1}$. The growth and survival of storage plantlets were observed comparing among the different treatments. The cultures were maintained under $40 \mu \mathrm{E} \mathrm{m}^{-2} \mathrm{~s}^{-1}$ light intensity, $16 \mathrm{~h} \mathrm{light/} 8 \mathrm{~h}$ dark photoperiod at $25^{\circ} \mathrm{C}$ without subculture. Height of plantlets, rate of growth and survival percentage were recorded every four weeks. Observations were made on plant height, number of shoots and number of nodes at the end of 28 weeks in culture. Presence of callus and roots was also recorded at this stage. After 28 weeks, plants under slow growth cultures were transferred to shoot proliferation medium. Regeneration percent was observed. The experiment was repeated thrice.

\section{Statistical analysis}

All the experiments were laid out in a completely randomized design (CRD) (Panse and Sukhatme 1985) with six replications and repeated. All data were subjected to analysis of variance (ANOVA) to detect significant difference between the means and expressed as $\pm \mathrm{SE}$.

Assessment of genetic fidelity of regenerants using RAPD technique

Genetic fidelity between the mother plants and randomly selected two months old, in vitro regenerated plants from slow growth studies established ex vitro was assessed by PCR based RAPD technique. Genomic DNA was extracted from young leaves $(0.5 \mathrm{~g})$ of the mother plants and regenerated plants. A cetyltrimethylammoniumbromide (CTAB) protocol (Murray and Thompson 1980) was adopted with slight modification for DNA extraction (Nair and Reghunath, 2009). DNA amplification was done using arbitrarily designed RAPD primers (Operon Inc., California, USA) adopting the procedure of William et al. (1990) with required modifications (Nair and Reghunath, 2009). The genetic fidelity was verified by comparing the RAPD banding pattern of regenerants with that of the mother plants.

\section{RESULT AND DISCUSSION}

Legumes, in general, are considered to be recalcitrant to in vitro culture (Tejavathi et al. 2010). Development of effective protocol for in vitro culture is a pre requisite for conservation and multiplication of germplasm of this threatened medicinal plant. In the study, the cultures were initiated from in vitro raised seedling explants. Seeds when inoculated directly into the hormone free MS medium, germination percentage was less than 20 even after two months in culture. Hence seeds were scarified by rubbing on a sand paper before inoculation, where by germination increased by 90 per cent within a month in culture. Adventitious bud regeneration and proliferation were attempted using single nodal segments and leaf bits. Only the nodal explants exhibited direct organogenesis. Explant source is one of the critical parameters for successful regeneration of legume species (Parrott et al. 1992). Nodal explants cultured on MS medium containing growth regulators (BA, Kn, IAA) singly as well as in combination showed various type of responses with respect to number of days for bud initiation, number of shoots regenerated per culture and number of nodes per shoot. Leaf bits did not give any morphogenetic response except for slight callusing at higher concentration of BA and Kn. Since callus mediated organogenesis may result in variation and cannot be considered for conservation studies, regeneration trials with leaf bits were excluded. The establishment of in vitro regeneration system from nodal explants produces true to type, genetically stable plants (Jain and Bashir 2010).

Nodal explants recorded 100 per cent survival irrespective of the presence or absence of growth regulators in the culture medium. The earliest bud initiation took place at an average of 5 days when cultured on MS medium supplemented with $1.0 \mathrm{mg} \mathrm{L}^{-1} \mathrm{BA}$ and $1.0 \mathrm{mg} \mathrm{L}^{-1} \mathrm{Kn}$. Treatments supplemented with either BA, Kn, or BA in combination with IAA gave the earliest bud initiation. Medium devoid of growth regulators as well as in treatments with $\mathrm{Kn}$-IAA combinations took a week or more to initiate buds. Nodal segments gave maximum 
proliferation on media supplemented with BA and IAA. BA in combination with a lower concentration of auxin, $1.0 \mathrm{mg}$ $\mathrm{L}^{-1} \quad \mathrm{BA}$ and $0.1 \mathrm{mg} \mathrm{\textrm {L } ^ { - 1 }}$ IAA gave maximum shoot proliferation of 4.67 shoots per culture and maximum number of nodes per shoot being 4.03 (Plate 1A). BA when used alone induced multiple shoots that were weak, fragile and vitrified. The synergistic effect of BA and IAA in multiplication and growth of shoots has been established in this study. A similar trend of cytokinin-auxin synergism was noticed for in vitro cultures of the legumes Clitoria ternatea (Rout 2005) and Macrotyloma uniflorum (Tejavathi et al. 2010). However, a lower ratio of BA to IAA resulted in a decline in the number of shoots per culture, due to basal callusing. Though synergistic effects of $\mathrm{BA}$ in combination with $\mathrm{Kn}$ has been reported in many plant species (Ashraf et al. 2014), in this context BA-Kn combinations did not bring about any significant enhancement in the number of shoots produced per culture. However, the combination produced longer shoots compared to those with Kn alone. Shoot proliferation was very low in $\mathrm{Kn}$ supplemented medium compared to that supplemented with BA. Similar findings were reported in Sida cordifolia (Sivanesan and Jeong, 2009) and Azadirchta indica (Arora et al. 2010). The media with low BA: Kn ratio also exhibited low shoot proliferation, which is in agreement with earlier report on Adhatoda vasica (Abhyankar and Reddy, 2007).

Shoot proliferation was very low (1.17 to 1.67 shoots per culture), in the treatments involving $\mathrm{Kn}$ alone or $\mathrm{Kn}$ in combination with IAA. The control treatment, MS medium devoid of plant growth hormones, did not support the induction of multiple shoots and invariably produced only one shoot per culture (Fig.1, 2 \& 3).
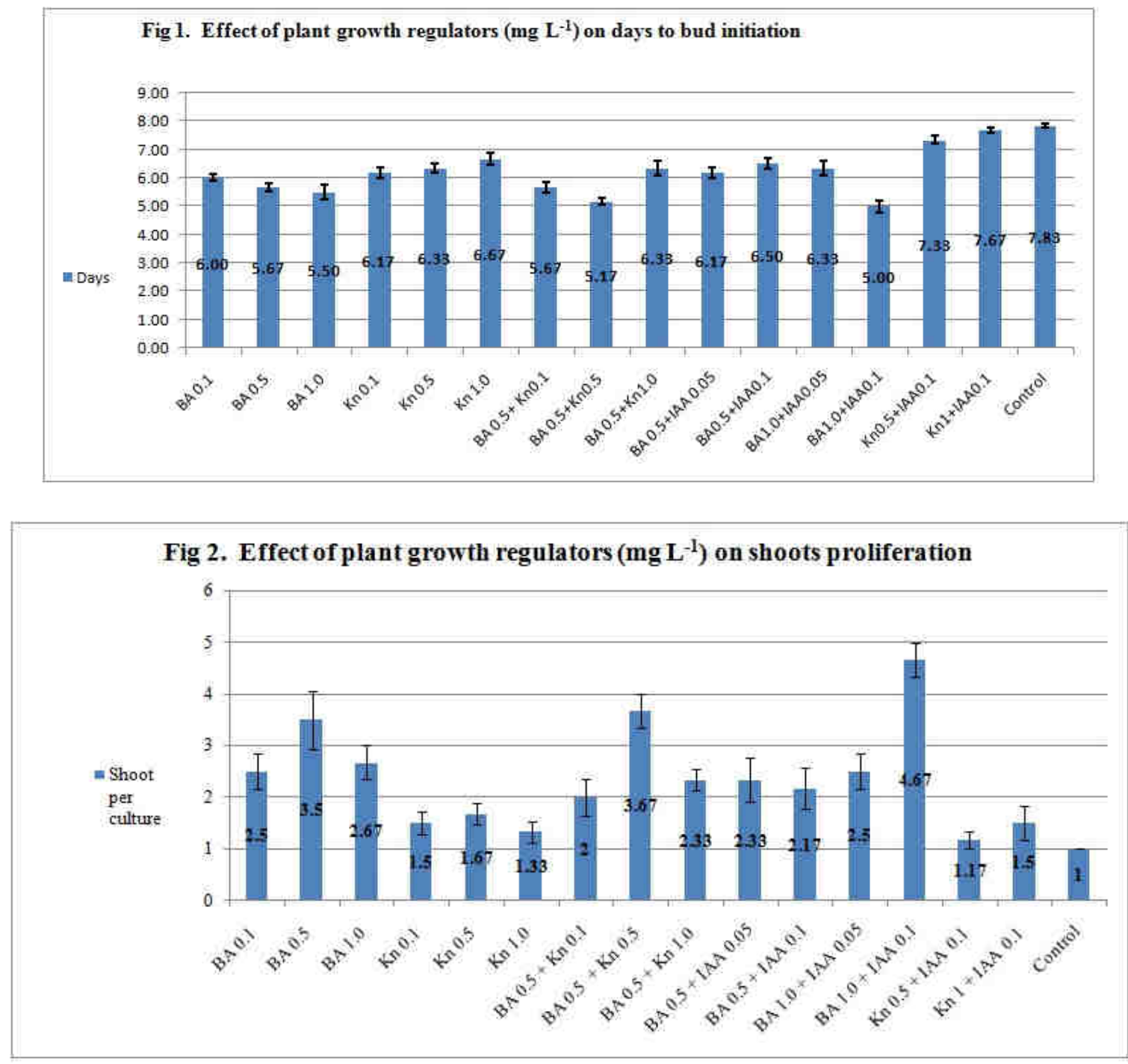
Fig 3. Effect of plant growth regulators $\left(\mathrm{mg} \mathrm{L}^{-1}\right)$ on number of nodes $\operatorname{shoot}^{-1}$

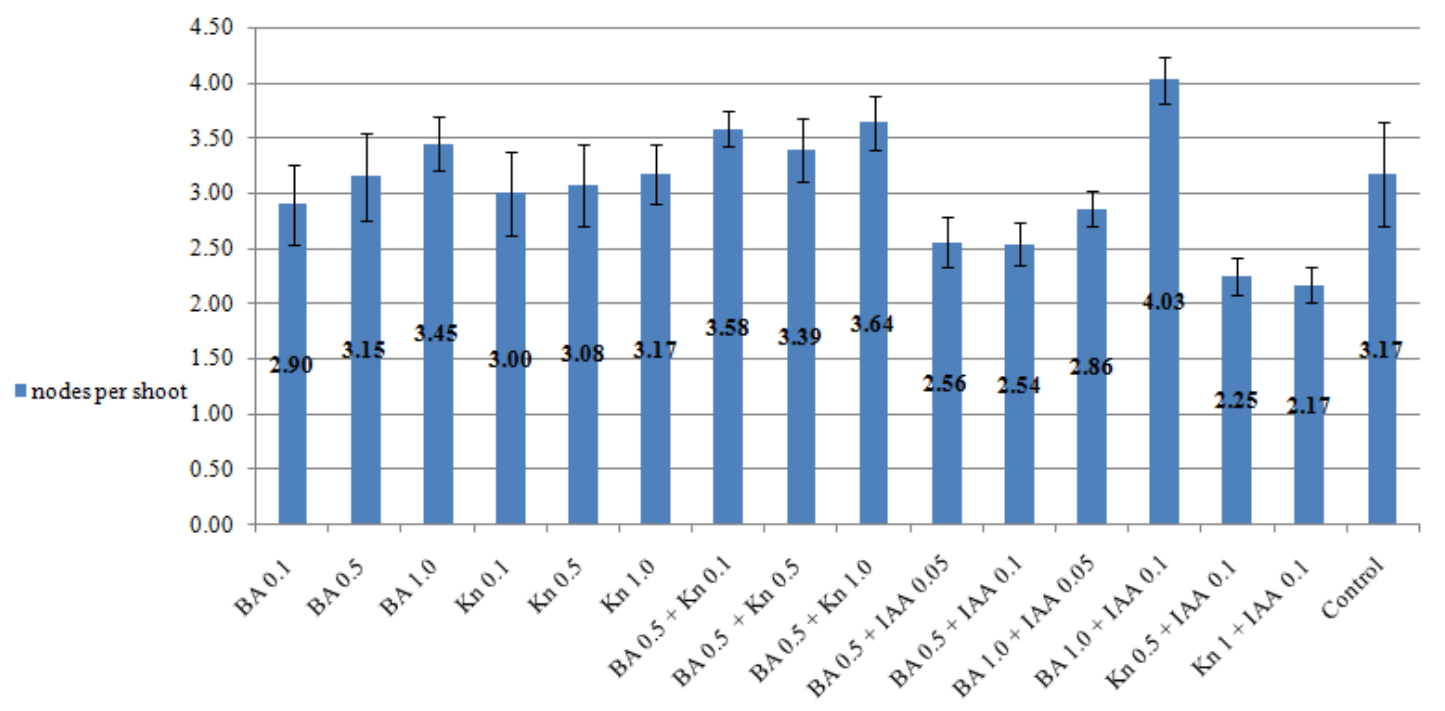

In the medium supplemented with $1.0 \mathrm{mg} \mathrm{L}^{-1} \mathrm{BA}$ and $0.1 \mathrm{mg} \mathrm{L}^{-1} \mathrm{IAA}$, the shoots proliferated at the rate of 1.5 times per subculture at four weeks interval. The shoots, after five subculture cycles were transferred to the same medium supplemented with different levels of $\mathrm{GA}_{3}$ for shoot elongation. A slight increase in shoot length was observed with increasing levels of $\mathrm{GA}_{3}$, though not significant (Table 1). The number of shoots per culture as well as nodes per shoot also did not show any significant variation. Hence an intermediary short elongation stage was excluded.

Table.1: Effect of gibberellic acid on enhanced release of axillary buds from nodal explants

\begin{tabular}{|l|c|c|c|c|}
\hline $\begin{array}{l}\text { Treatment } \\
\text { No. }\end{array}$ & $\begin{array}{c}\text { GA } \\
\left(\mathrm{mg} \mathrm{L}^{-1}\right)\end{array}$ & Shoots per culture & Shoot length & Nodes per shoot \\
\hline G1 & 1 & $4.50 \pm 1.90$ & $5.20 \pm 0.64$ & $3.61 \pm 0.52$ \\
G2 & 2 & $4.67 \pm 0.67$ & $5.22 \pm 2.05$ & $3.71 \pm 0.49$ \\
G3 & 3 & $4.50 \pm 1.90$ & $5.43 \pm 0.69$ & $4.00 \pm 0.84$ \\
Control & - & $4.67 \pm 0.67$ & $5.18 \pm 0.75$ & $4.03 \pm 0.26$ \\
\hline CD $(5 \%)$ & - & NS & NS & NS \\
\hline
\end{tabular}

The data represent mean of six replications Basal culture medium: MS + BA $1.0 \mathrm{mg} \mathrm{L}^{-1}+\mathrm{IAA} 0.1 \mathrm{mg} \mathrm{L}^{-1}$

Efficient rooting of in vitro regenerated shoots and subsequent field establishment is the final stage of rapid clonal propagation. Shoots measuring c.a. $5 \mathrm{~cm}$ were transferred to the rooting medium. The root initiated in different media within 12-17days of inoculation. The earliest initiation of roots (12.75 days) was obtained in the basal medium devoid of growth regulator and in the same medium supplemented with IAA $1.5 \mathrm{mg} \mathrm{L}^{-1}$. Media supplemented with IBA and NAA took an average of 15 days, for root initiation. Among the different auxins, tried IAA gave a higher rooting efficiency (Plate 1B) compared to IBA and NAA. Maximum root initiation (66.67 per cent) among the treatments, was obtained in the MS medium (with half strength macronutrients) supplemented with IAA 1.5 $\mathrm{mg} \mathrm{L}^{-1}$ after four weeks of incubation in rooting medium. The same treatment gave maximum number of roots of 4.25 as well as longer roots of $2.85 \mathrm{~cm}$, which is significantly higher compared to all other treatments (Table 2). Induction of rooting by IAA were reported in Spilanthes mauritiana (Bais et al. 2002) and Piper methysticum (Zhang et al. 2008). Well grown in vitro rooted plantlets when transferred to different potting media, recorded 91.67 per cent survival on sterilized sand, while soilrite alone and soilrite:sand in combination recorded low survival rate of 50 and 66.67 per cent respectively, under field condition (Plate 1C). 


\begin{tabular}{|c|c|cccc|}
\hline \multicolumn{7}{|c|}{ Table.2.: Effect of auxins on in vitro rooting of microshoots of I. tinctoria } \\
$\begin{array}{c}\text { Treatment } \\
\text { No. }\end{array}$ & $\begin{array}{c}\text { Auxins } \\
\left(\mathrm{mg} \mathrm{L}^{-1}\right)\end{array}$ & $\begin{array}{c}\text { Root } \\
\text { Initiation } \\
(\%)\end{array}$ & $\begin{array}{c}\text { Days to Root } \\
\text { Initiation }\end{array}$ & $\begin{array}{c}\text { No.of } \\
\text { Roots }\end{array}$ & $\begin{array}{c}\text { Mean root } \\
\text { length } \\
(\mathrm{cm})\end{array}$ \\
\hline R1 & IBA 0.50 & 16.67 & $15.00 \pm 0.50$ & $1.00 \pm 0.02$ & $1.50 \pm 0.18$ \\
R2 & IBA 1.00 & 16.67 & $17.00 \pm 0.20$ & $1.00 \pm 0.03$ & $1.90 \pm 0.09$ \\
R3 & IBA 1.50 & 50.00 & $16.00 \pm 1.40$ & $2.00 \pm 0.10$ & $1.76 \pm 0.01$ \\
R4 & IBA 2.00 & 50.00 & $15.67 \pm 0.25$ & $2.33 \pm 0.04$ & $2.21 \pm 0.04$ \\
R5 & IBA 2.50 & 50.00 & $15.00 \pm 0.40$ & $3.33 \pm 0.04$ & $2.14 \pm 0.03$ \\
R6 & IAA 1.00 & 33.33 & $15.00 \pm 0.50$ & $2.00 \pm 0.03$ & $0.92 \pm 0.01$ \\
R7 & IAA 1.50 & 66.67 & $12.75 \pm 0.18$ & $4.25 \pm 0.05$ & $2.85 \pm 0.08$ \\
R8 & IAA 2.50 & 50.00 & $13.33 \pm 0.57$ & $2.00 \pm 0.01$ & $1.61 \pm 0.02$ \\
R9 & NAA 0.50 & 33.33 & $15.50 \pm 0.09$ & $2.50 \pm 0.11$ & $1.18 \pm 0.04$ \\
R10 & NAA 1.00 & 50.00 & $15.67 \pm 0.10$ & $1.67 \pm 0.03$ & $1.23 \pm 0.02$ \\
R11 & NAA 1.50 & 16.66 & $15.00 \pm 0.20$ & $2.00 \pm 0.12$ & $1.15 \pm 0.01$ \\
R12 & NAA 2.00 & 33.33 & $15.00 \pm 0.70$ & $2.00 \pm 0.08$ & $1.35 \pm 0.01$ \\
Control & - & 33.33 & $12.75 \pm 0.28$ & $2.00 \pm 0.03$ & $0.90 \pm 0.01$ \\
\hline CD (5\% & & & 0.77 & 0.27 & 0.21 \\
\hline
\end{tabular}

The data represent mean of six replications Basal culture medium:1/2MS

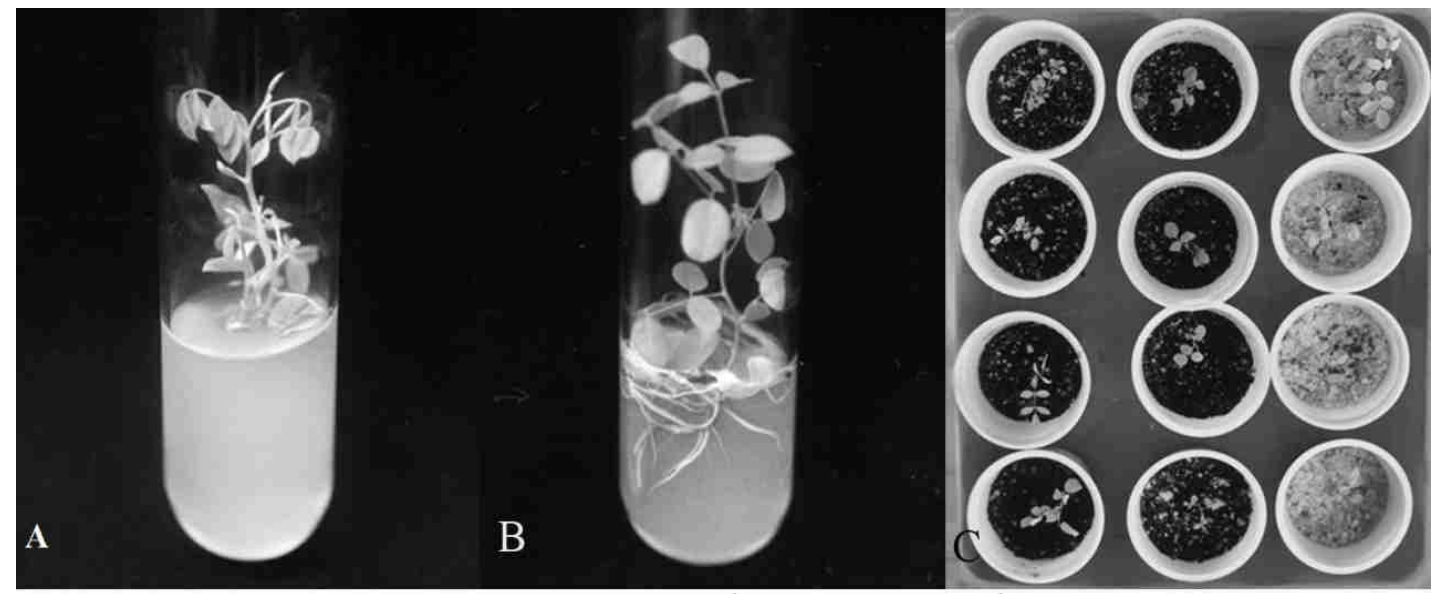

Plate 1. A) Shoot multiplication in $\mathrm{MS}+1.0 \mathrm{mg} \mathrm{L}^{-1}$ BA and $0.1 \mathrm{mg} \mathrm{L}^{-1}$ IAA B) In vitro rooting in $1 / 2 \mathrm{MS}+1.5 \mathrm{mg} \mathrm{L}^{-1}$ IAA C) Ex vitro establishment in different potting media

Ex vitro rooting facilitates cost reduction by avoiding in vitro rooting, reducing labour and time of establishment from laboratory to field (Shekhawat et al. 2015). In the study, pre treatment with IBA $1000 \mathrm{mg} \mathrm{L}^{-1}$ for 20 s recorded 75 per cent survival after four weeks of planting in sterilised sand in plastic cups compared to slow dip methods (Fig.4). Pandeya et al. (2010) reported ex vitro rooting using IBA quick dip method in Clitoria ternatea. 


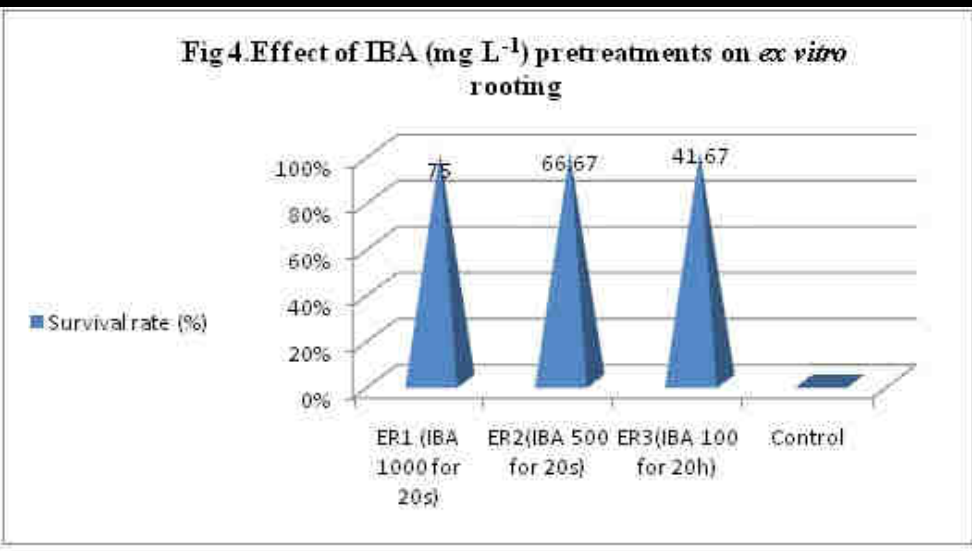

\section{In vitro conservation by inducing slow growth}

Among the treatments tried to select the basal medium for slow growth experiments, $1 / 2 \mathrm{MS}$ with IBA $0.5 \mathrm{mg} \mathrm{L}^{-1}$ gave the least plant height $(3.33 \mathrm{~cm})$, which was on par with $1 / 2$ MS without IBA. But senescence (indicated by wilting of leaves) initiated comparatively late in $1 / 2$ MS medium supplemented with IBA $0.5 \mathrm{mg} \mathrm{L}^{-1}$. The senescence did not occur up to 16 weeks in the cultures maintained in this medium, while in $1 / 2 \mathrm{MS}$ without IBA senescence initiated in 13 weeks. The treatments supplemented with IBA also initiated roots in culture (Table 3). In the study, the senescence indicated by wilting of leaves appeared late in auxin supplemented medium. The shoot development in terms of plant height was low in those treatments supplemented with IBA. Late senescence and low rate of growth were the candidate properties for the selection of the basal slow growth medium. Hence, $1 / 2$ MS with IBA $0.5 \mathrm{mg} \mathrm{L}^{-1}$ was selected as the best basal medium for inducing slow growth. Scocchi and Mroginski (2004) also confirmed that reducing concentration of mineral salt mixture in the medium retarded the growth of cultures and gave high survival rates.

Table.3: Effect of MS medium and IBA in inducing slow growth in Indigofera tinctoria

\begin{tabular}{|l|l|c|c|c|l|}
\hline T.No. & Media & $\begin{array}{c}\text { Plant } \\
\text { Height } \\
(\mathrm{cm})\end{array}$ & $\begin{array}{c}\text { Plant Height } \\
(\mathrm{cm})\end{array}$ & $\begin{array}{c}* * \text { Senescence } \\
(\text { weeks })\end{array}$ & \multicolumn{1}{|c|}{ Remarks } \\
\hline MS1 & $1 / 2 \mathrm{MS}$ & 5.08 & 5.77 & 12 & Rooting in $33.33 \%$ cultures \\
MS2 & $1 / 2 \mathrm{MS}+\mathrm{IBA}\left(0.5 \mathrm{mgl}^{-1}\right)$ & 4.48 & 5.50 & No senecence & Rooting in all cultures \\
MS3 & MS & 5.35 & 6.13 & 9 & Rooting in $16.67 \%$ cultures \\
MS4 & MS + IBA $\left(0.5 \mathrm{mgl}^{-1}\right)$ & 5.23 & 6.00 & 11 & Rooting in all cultures \\
\hline CD Value (5\%) & 0.61 & 0.44 & - & - \\
\hline F Value & 3.46 & 3.43 & - & - \\
\hline
\end{tabular}

*Observations were recorded after 16 weeks of incubation;** Senescence indicated by wilting of leaves

Addition of mannitol to the standardized slow growth medium could reduce the growth of I. tinctoria plantlets in terms of plant length. All treatments recorded lower plant height, shoot number and node number compared to control. The higher the concentration of mannitol added to the medium, the higher the reduction in plant length was observed. Presence of high concentration of mannitol in the culture medium produced osmotic effect that prevented normal uptake of the nutrients by the explants resulting in slow growth. The use of mannitol in reducing growth was reported in the cultures on Ipomoea batatas (Uyoh et al. 2003) and Plumbago indica ( Charoensub and Pansiri 2004), Coleus forskohlli (Dube et al. 2011). Mannitol $5 \mathrm{~g} \mathrm{~L}^{-1}$ recorded the highest plant length and mannitol $30 \mathrm{~g} \mathrm{~L}^{-1}$, the least in all stages of incubation. With regard to rate of growth, decreasing trend was noticed from eighth week onwards. The effect of different concentration of mannitol on rate of plant growth of I. tinctoria cultures at different lengths of incubation in vitro is illustrated in Fig.5. 
Fig 5. Effect of different levels of mannitol on rate of growth of I.tinctoria cultures at different lengths of incubation in vitro
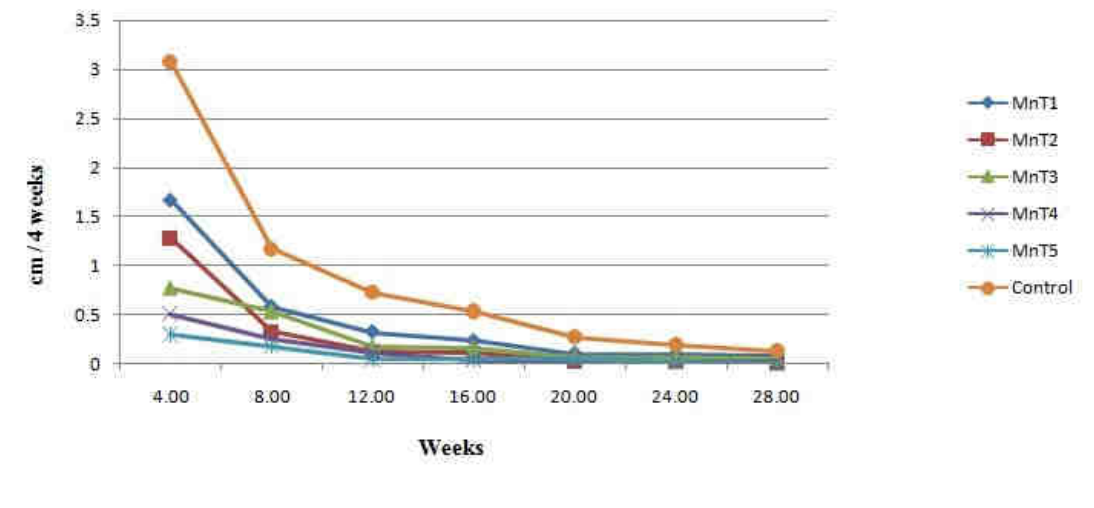

There was significant variation with regard to plant height, shoot number and number of nodes among different levels of mannitol after 28 weeks of incubation (Tables $4 \& 5$ ). The effect of different levels of mannitol on plant growth after 28 weeks of incubation in vitro is illustrated in Plate $2 \mathrm{~A}$.

Cent per cent survival was obtained with all levels of mannitol, 28 weeks after inoculation. At this stage, none of the cultures showed callusing but rooting. When transferred to regeneration medium, cent per cent regeneration was obtained in cultures with mannitol $5 \mathrm{~g} \mathrm{~L}^{-1}$ and mannitol $10 \mathrm{~g}$ $\mathrm{L}^{-1}$. The control plants recorded a low regeneration of 33.33 per cent on transfer to regeneration medium (Table 6). Slow growth basal medium with mannitol $30 \mathrm{~g} \mathrm{~L}^{-1}$ recorded maximum growth inhibition and cent per cent survival but recorded only 83.33 per cent regeneration when transferred to regeneration media after 28 weeks of incubation. Among those cultures which gave cent per cent regeneration 28 weeks after incubation, maximum plant growth inhibition was recorded in the medium supplemented with mannitol $10 \mathrm{~g} \mathrm{~L}^{-1}$. Cultures of $I$. tinctoria were maintained for 28 weeks without any subculture. Shoot regeneration after slow growth incubation in depicted in Plate 2B. The nodal cuttings from slow growth cultures when subcultured onto proliferation medium, attained same efficiency as in normal cultures with second subculture cycle.

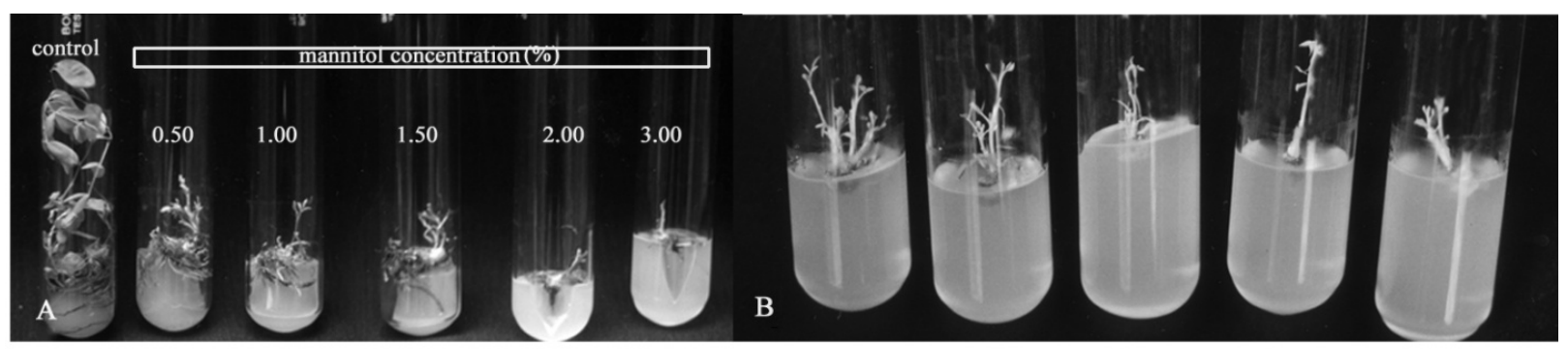

Plate 2. A) Effect of different levels of mannitol on shoot growth after 28 weeks in culture B) Shoot regeneration in $\mathrm{MS}+1.0 \mathrm{mg} \mathrm{L}^{-1} \mathrm{BA}+0.1 \mathrm{mg} \mathrm{L}^{-1}$ IAA after slow growth incubation period.

In the study, mannitol $10 \mathrm{~g} \mathrm{~L}^{-1}$ could induce maximum slow growth such that the Indigofera cultures could be maintained in vitro up to 28 weeks without subculture and on transfer to the proliferation medium after 28 weeks, 100 per cent regeneration could be obtained. Higher concentration of mannitol gave lower regeneration when survived cultures were inoculated on to regeneration medium. Too high a concentration of mannitol added to the media might be harmful and caused the death of plants in culture. Under usual laboratory conditions, with no addition of mannitol to the medium (control), subculture has to be done every four weeks. 
Table. 4: Effect of slow growth treatments on mean plant height and rate of growth of I. tinctoria cultures at different lengths of incubation in vitro

\begin{tabular}{|c|c|c|c|c|c|c|c|c|c|c|c|c|c|c|c|}
\hline \multirow{2}{*}{$\begin{array}{l}\text { Tr. } \\
\text { No. }\end{array}$} & \multirow{2}{*}{$\begin{array}{c}\text { Mannitol } \\
\left(\mathrm{g} \mathrm{L}^{-1}\right)\end{array}$} & \multicolumn{7}{|c|}{ Mean plant height $(\mathrm{cm})$} & \multicolumn{7}{|c|}{ Rate of growth $(\mathrm{cm} / 4$ weeks $)$} \\
\hline & & $\begin{array}{c}4 \\
\text { wk } \\
\text { s } \\
\end{array}$ & $\begin{array}{c}8 \\
\text { wk } \\
\text { s } \\
\end{array}$ & $\begin{array}{c}12 \\
\text { wks }\end{array}$ & $\begin{array}{c}16 \\
\text { wks }\end{array}$ & $\begin{array}{c}20 \\
\text { wks }\end{array}$ & $\begin{array}{c}24 \\
\text { wk } \\
\text { s }\end{array}$ & $\begin{array}{c}28 \\
\text { wk } \\
\text { s } \\
\end{array}$ & $\begin{array}{c}4 \\
\text { wk } \\
\text { s } \\
\end{array}$ & $\begin{array}{c}\mathbf{8} \\
\mathbf{w k} \\
\mathrm{s} \\
\end{array}$ & $\begin{array}{c}12 \\
\text { wks }\end{array}$ & $\begin{array}{c}16 \\
\text { wks }\end{array}$ & $\begin{array}{c}20 \\
\text { wk } \\
\text { s } \\
\end{array}$ & $\begin{array}{c}24 \\
\text { wks }\end{array}$ & $\begin{array}{c}28 \\
\text { wks }\end{array}$ \\
\hline MnT1 & 5 & $\begin{array}{c}1.6 \\
7 \\
\end{array}$ & $\begin{array}{c}2.2 \\
5 \\
\end{array}$ & 2.57 & 2.80 & 2.90 & $\begin{array}{c}2.9 \\
9\end{array}$ & $\begin{array}{c}3.0 \\
7\end{array}$ & $\begin{array}{c}1.6 \\
7\end{array}$ & $\begin{array}{c}0.5 \\
8\end{array}$ & 0.32 & 0.23 & $\begin{array}{c}0.1 \\
0\end{array}$ & 0.09 & 0.08 \\
\hline MnT2 & 10 & $\begin{array}{c}1.2 \\
8 \\
\end{array}$ & $\begin{array}{c}1.6 \\
0 \\
\end{array}$ & 1.72 & 1.82 & 1.85 & $\begin{array}{c}1.8 \\
7 \\
\end{array}$ & $\begin{array}{c}1.8 \\
8 \\
\end{array}$ & $\begin{array}{c}1.2 \\
8 \\
\end{array}$ & $\begin{array}{c}0.3 \\
2 \\
\end{array}$ & 0.12 & 0.10 & $\begin{array}{c}0.0 \\
3 \\
\end{array}$ & 0.02 & 0.01 \\
\hline MnT3 & 15 & $\begin{array}{c}0.7 \\
7 \\
\end{array}$ & $\begin{array}{c}1.3 \\
0\end{array}$ & 1.47 & 1.63 & 1.70 & $\begin{array}{c}1.7 \\
7 \\
\end{array}$ & $\begin{array}{c}1.8 \\
2 \\
\end{array}$ & $\begin{array}{c}0.7 \\
7 \\
\end{array}$ & $\begin{array}{c}0.5 \\
3 \\
\end{array}$ & 0.17 & 0.16 & $\begin{array}{c}0.0 \\
7\end{array}$ & 0.07 & 0.05 \\
\hline MnT4 & 20 & $\begin{array}{c}0.5 \\
0\end{array}$ & $\begin{array}{c}0.7 \\
5\end{array}$ & 0.87 & 0.90 & 0.93 & $\begin{array}{c}0.9 \\
5\end{array}$ & $\begin{array}{c}0.9 \\
7\end{array}$ & $\begin{array}{c}0.5 \\
0\end{array}$ & $\begin{array}{c}0.2 \\
5\end{array}$ & 0.12 & 0.03 & $\begin{array}{c}0.0 \\
3\end{array}$ & 0.02 & 0.02 \\
\hline MnT5 & 30 & $\begin{array}{c}0.3 \\
0 \\
\end{array}$ & $\begin{array}{c}0.4 \\
8 \\
\end{array}$ & 0.53 & 0.58 & 0.62 & $\begin{array}{c}0.6 \\
4 \\
\end{array}$ & $\begin{array}{c}0.6 \\
4 \\
\end{array}$ & $\begin{array}{c}0.3 \\
0\end{array}$ & $\begin{array}{c}0.1 \\
8 \\
\end{array}$ & 0.05 & 0.05 & $\begin{array}{c}0.0 \\
4 \\
\end{array}$ & 0.02 & 0.00 \\
\hline $\begin{array}{c}\text { Contr } \\
\text { ol }\end{array}$ & $\begin{array}{c}\text { Sucrose } \\
\left(\mathrm{g} \mathrm{L}^{-1}\right) \\
30\end{array}$ & $\begin{array}{c}3.0 \\
8\end{array}$ & $\begin{array}{c}4.2 \\
5\end{array}$ & 4.98 & 5.51 & 5.78 & $\begin{array}{c}5.9 \\
7\end{array}$ & $\begin{array}{c}6.1 \\
0\end{array}$ & $\begin{array}{c}3.0 \\
8\end{array}$ & $\begin{array}{c}1.1 \\
7\end{array}$ & 0.73 & 0.53 & $\begin{array}{c}0.2 \\
7\end{array}$ & 0.19 & 0.13 \\
\hline
\end{tabular}

The data represent mean of only live plants; Basal culture medium: $1 / 2 \mathrm{MS}+\mathrm{IBA} 0.5 \mathrm{mg} \mathrm{L}^{-1}$; wks - weeks

Table.5: Effect of effective slow growth treatments on morphological parameters after 28 weeks of incubation of I. tinctoria cultures in vitro

\begin{tabular}{|c|c|c|c|c|c|}
\hline \multirow{2}{*}{$\begin{array}{l}\text { Tr. } \\
\text { No. }\end{array}$} & \multirow{2}{*}{$\begin{array}{c}\text { Mannitol } \\
\left(\mathrm{g} \mathrm{L}^{-1}\right)\end{array}$} & \multicolumn{4}{|c|}{28 weeks after incubation } \\
\hline & & $\begin{array}{c}\text { Plant } \\
\text { height }(\mathrm{cm})\end{array}$ & No.of shoots & No of nodes & Remarks \\
\hline MnT1 & 5 & 3.07 & 1.33 & 3.17 & $\begin{array}{l}\text { Callus absent, Root } \\
\text { present }\end{array}$ \\
\hline $\mathrm{MnT} 2$ & 10 & 1.88 & 1.17 & 2.17 & $\begin{array}{l}\text { Callus absent, Root } \\
\text { present }\end{array}$ \\
\hline MnT3 & 15 & 1.82 & 1.17 & 2.00 & $\begin{array}{l}\text { Callus absent, Root } \\
\text { present }\end{array}$ \\
\hline MnT4 & 20 & 0.97 & 1.00 & 1.00 & $\begin{array}{l}\text { Callus absent, Root } \\
\text { present }\end{array}$ \\
\hline MnT5 & 30 & 0.63 & 1.00 & 1.00 & $\begin{array}{l}\text { Callus absent, Root } \\
\text { present }\end{array}$ \\
\hline Control & $\begin{array}{c}\text { Sucrose }(\mathbf{g} \\
\left.\mathbf{L}^{\mathbf{- 1}}\right) \\
30\end{array}$ & 6.10 & 1.50 & 6.50 & $\begin{array}{l}\text { Callus absent, Root } \\
\text { present }\end{array}$ \\
\hline $\mathrm{CD}(5 \%)$ & - & 0.88 & 0.32 & 0.86 & - \\
\hline F value & - & 27.27 & 2.01 & 26.24 & - \\
\hline
\end{tabular}

The data represent mean of six replications; Basal culture medium: $1 / 2 \mathrm{MS}+\mathrm{IBA} 0.5 \mathrm{mg} \mathrm{L}^{-1}$

Table. 6: Effect of slow growth treatments on survival (Sl) and regeneration $(R)$ of Indigofera tinctoria cultures at different lengths of incubation in vitro

\begin{tabular}{|c|c|c|c|c|c|c|c|c|c|}
\hline $\begin{array}{l}\text { Tr. } \\
\text { No. }\end{array}$ & $\begin{array}{c}\text { Mannitol } \\
\left(\mathrm{g} \mathrm{L}^{-1}\right)\end{array}$ & $\begin{array}{l}4 \text { wks } \\
\text { Sl (\%) }\end{array}$ & $\begin{array}{l}8 \text { wks } \\
\text { Sl (\%) }\end{array}$ & $\begin{array}{l}2 \text { wks } \\
\text { Sl (\%) }\end{array}$ & $\begin{array}{l}16 \text { wks } \\
\text { SI }(\%)\end{array}$ & $\begin{array}{c}20 \text { wks } \\
\text { Sl( } \%)\end{array}$ & $\begin{array}{c}24 \text { wks } \\
\text { SI( } \%)\end{array}$ & $\begin{array}{c}28 \text { wks } \\
\text { Sl }(\%)\end{array}$ & R\% \\
\hline MnT1 & 5 & 100.00 & 100.00 & 100.00 & 100.00 & 100.00 & 100.00 & 100.00 & $100.00^{\mathrm{S}}$ \\
\hline MnT2 & 10 & 100.00 & 100.00 & 100.00 & 100.00 & 100.00 & 100.00 & 100.00 & $100.00^{\mathrm{S}}$ \\
\hline
\end{tabular}




\begin{tabular}{|c|c|c|c|c|c|c|c|c|c|}
\hline MnT3 & 15 & 100.00 & 100.00 & 100.00 & 100.00 & 100.00 & 100.00 & 100.00 & $83.33^{s}$ \\
\hline MnT4 & 20 & 100.00 & 100.00 & 100.00 & 100.00 & 100.00 & 100.00 & 100.00 & $83.33^{\mathrm{S}}$ \\
\hline MnT5 & 30 & 100.00 & 100.00 & 100.00 & 100.00 & 100.00 & 100.00 & 100.00 & $83.33^{S}$ \\
\hline Control & $\begin{array}{c}\text { Sucrose (g } \\
\left.\mathbf{L}^{-1}\right) \\
30\end{array}$ & 100.00 & 100.00 & 100.00 & 100.00 & 100.00 & 100.00 & 100.00 & $33.33^{D}$ \\
\hline
\end{tabular}

S: subcultured; D: discarded; Regeneration medium: MS + BA $1.0 \mathrm{mg} \mathrm{L}^{-1}+$ IAA 0.1 mg $\mathrm{L}^{-1}$

Genetic fidelity assessment of regenerants using random amplification of polymorphic DNA

Genetic uniformity is one of the most important prerequisites in the micropropagation as well as conservation of crop species. It is, therefore, essential to establish genetic uniformity of regenerates from the tissue culture system. The DNA of regenerated plants from slow growth treatment and that of control were extracted and amplified using six primers. Six decamer primers selected for the study with their nucleotide sequences in 5'-3' direction are Operon A4 (AATCGGGCTG), A10 (GTGATCGCAG), B1 (GTTTCGCTCC), B4 (GGACTGGAGT), B5 (TGCGCCCTTC) and B18 (CCACAGCAGT). All the six primers produced clear and reproducible bands. The number of bands of each primer varied from three to six. RAPD fragment pattern for plantlets recovered from slow growth induction were identical to those of control plants for all the six primers tested. Polymerase chain reaction (PCR) based technique, random amplified polymorphic DNA (RAPD) is immensely useful in establishing the genetic stability of in vitro regenerated plantlets in many crop species (Lakshmanan et al. 2007; Joshi and Dhawan 2007).

\section{CONCLUSION}

The present study provides an efficient protocol for rapid clonal propagation of $I$. tinctoria in vitro. This method vividly illustrates the association of BA with IAA in shoot proliferation. Short term in vitro conservation by inducing slow growth using the osmoticum, $10 \mathrm{~g} \mathrm{~L}^{-1}$ mannitol, would maintain the culture without subculturing upto 28 weeks, which results in a substantial reduction in labour and resources for maintaining the culture. Also, the genetic integrity of in vitro regenerated plants from slow growth medium were confirmed by RAPD analysis. Hence, the protocol can be effectively utilized for the in vitro conservation of its germplasm.

\section{ACKNOWLEDGEMENT}

The financial assistance and facilities provided for the research work by Kerala Agricultural University, India is greatly acknowledged. We also acknowledge the Director of Research, Kerala Agricultural University, for facilitating the conduct of the project

\section{REFERENCES}

[1] Abhyankar G and Reddy VD (2007) Rapid micropropagation via axillary bud proliferation of Adhatoda vasica Nees from nodal segments. Indian J Exp Biol. 45:268-71.

[2] Arora K, Sharma M, Srivastava J and Ranade SA (2010) Rapid in vitro cloning of a 40- year-old tree of Azadirachta indica A. Juss. (Neem) employing nodal stem segments. Agroforest Syst. 8: 53-63. doi: http://dx.doi.org/10.1007/s10457-009-9230-1

[3] Ashraf MF, Aziz MA, Kemat N and Ismail I (2014) Effect of cytokinin types, concentrations and their interactions on in vitro shoot regeneration of Chlorophytum borivilianum Sant. \& Fernandez. Electronic J. Biotechnol. 17:275-279. http://dx.doi.org/10.1016/j.ejbt.2014.08.004

[4] Asuntha, G, Prasannaraju Y, Prasad KVSRG (2010) Effect of Ethanol Extract of Indigofera tinctoria Linn (Fabaceae) on lithium / pilocarpine-induced status epilepticus and oxidative stress in Wistar rats. Trop. J. Pharm. Res. 9:149-156. http://dx.doi.org/10.4314/tjpr.v9i2.53702

[5] Bais HP, Green JB, Walker TS, Okemo PO and Vivanco JM (2002) In vitro propapagtaion of Spilanthes mauritiana DC., an endangered medicinal herb through axillary bud cultures. In Vitro Cell Dev. Biol. 38: 598-601. http://dx.doi.org/10.1079/IVP2002345

[6] Bangar AV and Saralaya MG (2011) Anti hyperglycemic activity of ethanol extract and chloroform extract of Indigofera tinctoria leaves in streptozotocin induced diabetic mice. Res. J. Pharm. Biol. Chem. Sci. 2:445-455. http://dx.doi.org/10.1155/2011/430237

[7] Barik DP, Naik SK, Mudgal A and Chand PK (2007) Rapid plant regeneration through in vitro axillary shoot proliferation of butterfly pea (Clitoria ternatea L.) - a twinning legume. In Vitro Cell Dev 
Biol Plant. 43:144-148. DOI:

http://dx.doi.org/10.1007/s11627-007-9040-y

[8] Charoensub $\mathrm{R}$ and Phansiri S (2004) In vitro conservation of rose coloured leadwort: Effect of mannitol on growth of plantlets. Kasetsart J. (Nat. Sci.) 38: 97- 102.

[9] Cragg GM and Newman DG (2006) Plants as a source of anti-cancer agents- Ethanopharmacology. In Elisabetsky E and Etkin NL (eds).) Encyclopedia of Life Support System (EOLLS), Oxford, UK.

[10] Dube P, Gangopadhyay M, Dewanjee S and Ali N (2011) Establishment of a rapid multiplication protocol of Coleus forskohlii Briq. and in vitro conservation by reduced growth. Indian J. Biotechnol. 10: .228-231.

[11]Evans PK (1990) Indigofera sp. In Bajaj YPS (ed.) Biotechnology in Agriculture and Forestry. Legumes and Oilseed Crops. Part I. Springer Verlang, Berlin, p. 645-657.

[12] Jain A and Bashir M (2010) In vitro propagation of a medicinal plant- Portulaca grandiflora. Hook. World J. Agric. Sci. 6: 327-330.

[13] Joshi P and Dhawan V (2007) Assessment of genetic fidelity of micropropagated Swertia chirayita plantlets by ISSR marker assay. Biol Plant. 51:22-26. DOI: http://dx.doi.org/10.1007/s10535-007-0005-0

[14] Joy PP, Thomos J, Mathew S and Skari PS (1998) Medicinal Plants. Kerala Agriculture University, Aromatic and Medicinal Plant Research Station, Kerala, India, p. 73-74.

[15]Lakshmanan V, Venkataramareddy SR and Neelwrane B (2007)Molecular analysis of genetic stability in lingterm micropropagated shoots of banana using RAPD and ISSR markers. Electronic J. Biotech. 10:1-8. http://dx.doi.org/10.2225/vol10-issue5-fulltext-12

[16] Madhanmohan E, Mohan K and Amudha P (2010) Effect of Indigofera tinctoria on neurotransmitters concentrations in rat brain after induction of seizure. Intl. J. Phytopharmacol. 1:23-27.

[17] Mattapha S and Chantaranothai P (2012) The genus Indigofera L. (Leguminosae) in Thailand. Tropical Natural History. 12:207-244, 2012.

[18] Motamarri SN, Karthikeyan M, Rajasekar S and Gopal $\mathrm{V}$ (2012) Indigofera tinctoria Linn - A Phytopharmacological Review. International Journal of Research in Pharmaceutical and Biomedical Sciences. 3: 164-169.

[19] Murray HG and Thompson WF (1980) Rapid isolation of high molecular weight DNA. Nucleic Acids Res. 8:4321-4325. doi: 10.1093/nar/8.19.4321
[20] Murashige T and Skoog F (1962) A Revised Medium for Rapid Growth and Bio Assays with Tobacco Tissue Cultures. Physiol. Plant. 15: 473-497. http://dx.doi.org/10.1111/j.1399-3054.1962.tb08052.x

[21] Muthulingam M, Mohandoss $\mathrm{P}$, Indra $\mathrm{N}$ and Sethupathy S (2010) Antihepatotoxic efficacy of Indigofera tinctoria (Linn.) on paracetamol induced liver damage in rats. Int. J. Pharm. Biomed. Res. 1: 1318.

[22] Nair DS and Reghunath BR (2009) Cryoconservation and regeneration of axillary shoot meristems of Indigofera tinctoria (L.) by encapsulation-dehydration technique. In Vitro Cell Dev Biol-Plant 45: 565-573. http://dx.doi.org/10.1007/s11627-009-9244-4

[23] Pandeya K, Tiwari KN, Singh J, Verma JP and Dubey SD (2010) In vitro propagation of Clitoria ternatea L.: A rare medicinal plant. Journal of Medicinal Plants Research. 4:664-668. http://dx.doi.org/10.5897/JMPR09.418

[24] Panse VG and Sukhatme PV (1985) Statistical Methods for Agricultural Workers. ICAR, New Delhi, p.197.

[25] Parrott WA, Bailey MA, Durham RE and Mathews HV (1992) Tissue culture and regeneration in legumes. In Moss DP (ed.) Biotechnology and Crop Improvement in Asia. International Crops Research Institute for the Semi-Arid Tropics, Patancheru, A.P, India, p. 115-148.

[26] Rao NK (2004) Plant genetic resources- Advancing conservation and use through biotechnology. African J Biotech. 3 : 3 136-145. http://dx.doi.org/10.5897/AJB2004.000-2025

[27] Renukadevi KP and Sultana SS (2011) Determination of anti bacterial, antioxidant and cytotoxicity effect of Indigofera tinctoria on lung cancer cell line NCI-h69. Int. J. $\quad$ Pharm.7:356-362. http://dx.doi.org/10.3923/ijp.2011.356.362.

[28]Rout GR (2005) Micropropagation of Clitoria ternatea Linn. (Fabaceae)-An important medicinal plant. In Vitro Cell. Dev. Biol. Plant. 41:516-519. http://dx.doi.org/10.1079/IVP2005675.

[29] Salvi ND, George L and Eapen S (2001) Plant regeneration from leaf base callus of turmeric and random amplified polymorphic DNA analysis of regenerated plants. Plant Cell Tiss Organ Cult. 66:113119. http://dx.doi.org/10.1023/A:1010638209377

[30] Saravanakumar A, Gandhimathi R, Mohanalakshmi S, Nair R and Ashokkumar CK (2009) Evaluation of the antinociceptive properties from Indigofera tinctoria leaves extracts. J. Pharm. Sci. \& Res. 1 : 31-37. 
[31] Shekhawat MS, Kannan N, Manokari M and Ravindran CP (2015) In vitro regeneration of shoots and ex vitro rooting of an important medicinal plant Passiflora foetida L. through nodal segment cultures. Journal of Genetic Engineering and Biotechnology.13: 209-214. http://dx.doi.org/10.1016/j.jgeb.2015.08.002

[32] Sivanesan I and Jeong BR (2007) Direct shoot regeneration from nodal explants of Sida cordifolia Linn. In Vitro Cell. Dev. Biol. Plant. 43: 436-441. http://dx.doi.org/10.1007/s 11627-007-9090-1.

[33] Scocchi AM and Mroginski LA (2004) In vitro conservation of apical meristem-tip of Melia azedarach L. Meliaceae under slow-growth conditions. Phyton, International Journal of Experimental Botany. 73: 137-143.

[34] Tejavathi, DH, Devaraj VR, Murthy SM, Anitha P and Nijagunaiah R (2010) Regeneration of multiple shoots from the callus cultures of Macrotyloma uniflorum (Lam.) Verdc. Indian J. Biotech. 9:101-105.

[35] Uyoh EA, Nkang AE and Eneobong EE (2003) Biotechnology, genetic conservation and sustainable use of bioresources. Afr. J. Biotechnol. 2: 704 - 709 . http://dx.doi.org/10.5897/AJB2003.000-1129

[36] Verma P, Mathur AK, Jain SP and Mathur A (2012) In vitro conservation of twenty-three overexploited medicinal plants belonging to the Indian subcontinent. The Scientific World Journal.2012:1-10. http://dx.doi.org/10.1100/2012/929650.

[37] Williams JGK, Kubelik AR, Livak KJ, Rafalski JA and Tingey SV (1990) DNA polymorphisms amplified by arbitrary primers are useful as genetic markers. Nucleic Acids Res., 18: 6531-6535. http://dx.doi.org/10.1093/nar/18.22.6531

[38]Zhang Z, Zhao L, Chen X and Zheng X (2008) Sucessful micropropagation protocol of Piper methysticum. -Biologia Plantarum. 52: 110-112. http://dx.doi.org/10.1007/s10535-008-0020-9. 